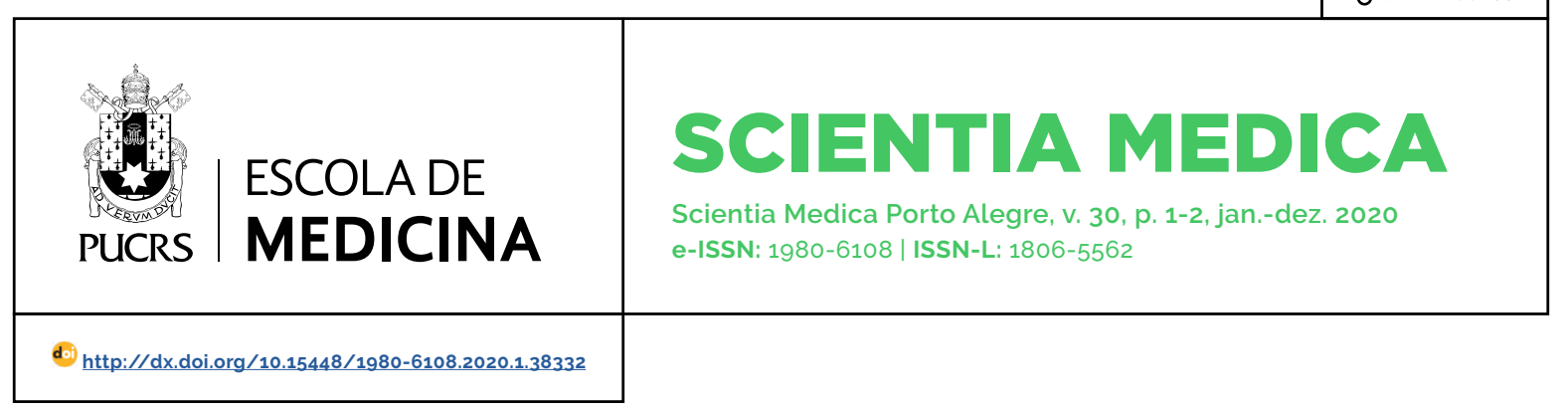

APRESENTAÇÃO

\title{
PANDEMIA, INFORMAÇÕES, EDUCAÇÃO, SAÚDE E MUDANÇA
}

\author{
PANDEMIC, INFORMATION, EDUCATION, HEALTH AND CHANGE
}

\section{Alexander Sapiro ${ }^{1}$ orcid.org/0000-0002-4105-617X alexander.sapiro@pucrs.br}

Ivan Carlos Antonello' orcid.org/0000-0003-4757-440X ivan.antonello@pucrs.br

\section{Luiz Gustavo}

\section{Guilhermano $^{1}$}

orcid.org/0000-0001-6664-7323

luiz.guilhermano@pucrs.br

Recebido em: 01 jun. 2020 Aceito em: 03 jun. 2020. Publicado em: 15 jun. 2020.

\section{(c) (i)}

Artigo está licenciado sob forma de uma licença Creative Commons Atribuição 4.0 Internacional.

\section{Palavras-Chave: coronavirus, pneumonia, COVID-19.}

Key-words: coronavirus, pneumonia, COVID-19.

Evidências científicas tornaram-se a base para escolhas pedagógicas, diagnósticas e terapêuticas, assim que educação e saúde passaram a necessitar de avaliação da força e qualidade das informações, para estabelecerem suas diretrizes no acompanhamento de um grupo de pessoas. No entanto, nem professores, tampouco médicos, atendem agrupamentos, e sim sujeitos, com nome, sobrenome, registro geral, capacidades, contexto social e, portanto, as orientações são adaptadas para cada indivíduo, que é único e existe quando identificado pelo outro. O reconhecimento se faz pela aproximação, olhar, escuta e observação dos sinais, dos sentimentos despertados, da semântica demonstrada no encontro entre seres humanos. Pois estamos afastados, enfrentamos tempos diferentes, não imaginados por nossa geração, com infecção viral planetária apontando para uma época de transmissão globalizada. Como fazem professores e profissionais da saúde que exercem profissões do encontro e, de repente, desencontram-se das pessoas?

Sobreviver passa a ser a palavra de ordem, aprender torna-se a ferramenta da vez e viver só é a proteção anunciada. Novos problemas, mais recentes que o novo COVID, aproximam-se celeremente: a informação de qualidade duvidosa, o isolamento, a solidão, a tristeza e o medo da doença e de não ter com quem contar. O tempo é de diminuição do ritmo, reflexão e resiliência, tentando impedir que a crise de fora cause uma crise para dentro, mas é difícil. Dizem que aumentou o número de casos novos, de mortos, de desempregados e de suicídios. As notícias trazem pânico e as redes sociais carecem de um sistema eficiente que avalie a qualidade de informação. Passamos a experimentar o que não sabíamos e, mesmo, o que não aceitávamos na área da educação em saúde, que é o ensino à distância e o atendimento com transferência remota de dados, dores e sentimentos. Docentes e profissionais de saúde assustados se tornam mais vulneráveis e humanos. Comovem-se com as 
iniquidades e deixam correr uma lágrima quando veem pela janela, um menino triste carregando algodão doce para vender em uma praça vazia de pessoas em isolamento horizontal.

\section{Alexander Sapiro}

Médico Pediatra, com título de especialista em Pediatria pela Sociedade Brasileira de Pediatria, especialista em Neonatologia pelo The John Radcliffe Hospital (Oxford, Inglaterra, Mestre em Pediatria e Saúde da Criança pela Pontificia Universidade Católica do Rio Grande do Sul (PUCRS, Porto Alegre, RS, Brasil), Professor da Escola de Medicina e membro do Projeto Integrado de Medicina e Letras (PRIMEL) da Pontificia Universidade Católica do Rio Grande do Sul (PUCRS, Porto Alegre, RS, Brasil),

\section{Ivan Carlos Antonello}

Médico Nefrologista, com título de especialista em Nefrologia pela Sociedade Brasileira de Nefrologia, Mestre em Nefrologia pela Universidade Federal do Rio Grande do Sul (UFRGS, Porto Alegre, RS, Brasil), Doutor em Medicina pela Pontifícia Universidade Católica do Rio Grande do Sul (PUCRS, Porto Alegre, RS, Brasil), Professor Titular da Escola de Medicina, dos Cursos de Graduação e Pós-Graduação e membro do Projeto Integrado de Medicina e Letras (PRIMEL) da Pontifícia Universidade Católica do Rio Grande do Sul (PUCRS, Porto Alegre, RS, Brasil),

\section{Luiz Gustavo Guilhermano}

Médico Psiquiatra, com título de especialista em Psiquiatria pela Associação Brasileira de Psiquiatria, Mestre em Farmacologia pela Universidade Federal de Ciências da Saúde de Porto Alegre (UFCSPA, Porto Alegre, RS, Brasil), Professor da Escola de Medicina da Pontifícia Universidade Católica do Rio Grande do Sul (PUCRS) e da residência médica em psiquiatria do Hospital São Lucas da PUCRS e membro do Projeto Integrado de Medicina e Letras (PRIMEL) da PUCRS (Porto Alegre, RS, Brasil).

\section{CORRESPONDÊNCIA:}

Alexander Sapiro

Escola de Medicina - Pontifícia Universidade Católica do Rio Grande do Sul

Av. Ipiranga, 6.681, Prédio 12A - $2^{\circ}$ andar, sala 202

Partenon, 97010-082

Porto Alegre, RS, Brasil 